\title{
Xeno-free serum replacement for ex vivo culture and expansion of $\mathrm{T}$ cells
}

\author{
Karoline W Schjetne ${ }^{1 *}$, Grethe Økern ${ }^{1}$, Sandra Kuligowski ${ }^{2}$, Tanja Aarvak ${ }^{1}$ \\ From Society for Immunotherapy of Cancer 29th Annual Meeting \\ National Harbor, MD, USA. 6-9 November 2014
}

\section{Background}

The manufacture of a majority of clinical $\mathrm{T}$ cell products for immunotherapy applications requires ex vivo $\mathrm{T}$ cell culture and expansion. Commercialization of $\mathrm{T}$ cell manufacturing processes requires reagents that meet regulatory guidelines and ultimately help reduce manufacturing cost of goods. A key component in many $\mathrm{T}$ cell culture protocols is human serum, which is expensive and may require testing prior to use for the manufacture of a cGMP-compliant $\mathrm{T}$ cell product. To this end, we have developed a xeno-free serum replacement supplement with defined components that can be used in combination with several different cell culture media to support ex vivo expansion of $\mathrm{T}$ cells.

\section{Results}

$\mathrm{T}$ cells activated ex vivo and expanded with Dynabeads ${ }^{\circledR}$ CD3/CD28 CTSTM and cultured in OpTmizer ${ }^{\mathrm{TM}}$ CTS ${ }^{\text {TM }}$, X-VivoTM 15, or AIM-V ${ }^{\circledR}$ CTS $^{\text {TM }}$ supplemented with pooled human serum or serum free $\mathrm{T}$ cell serum replacement showed similar growth kinetics, total fold expansion and transduction efficiency after 2 weeks in culture. Numbers of expanded CD4+ and CD8+ T cells were comparable in the expanded cultures regardless in the presence of human serum or the newly developed SRS-XF. Restimulated T cells expanded in serum free $\mathrm{T}$ cell serum replacement show similar cytokine profile and proliferation as $\mathrm{T}$ cells expanded in human serum.

\section{Conclusion}

This study shows that human serum may be replaced by a xeno-free formulation in several commonly used cell culture media to support ex vivo expansion and lentiviral transduction of polyclonal $\mathrm{T}$ cells. Culturing $\mathrm{T}$ cells in serum free $\mathrm{T}$ cell serum replacement facilitates a

${ }^{1}$ Thermo Fisher Scientific, Oslo, Norway

Full list of author information is available at the end of the article favourable culture profile and immune function. The serum free $T$ cell serum replacement contains only fully tested human-derived or human recombinant proteins which facilitates supply security for clinical large scale and commercial therapies.

\section{Authors' details}

${ }^{1}$ Thermo Fisher Scientific, Oslo, Norway. ${ }^{2}$ Thermo Fisher Scientific, Grand Island, United States.

Published: 6 November 2014

doi:10.1186/2051-1426-2-S3-P37

Cite this article as: Schjetne et al:: Xeno-free serum replacement for ex vivo culture and expansion of T cells. Journal for ImmunoTherapy of Cancer 2014 2(Suppl 3):P37.

Submit your next manuscript to BioMed Central and take full advantage of:

- Convenient online submission

- Thorough peer review

- No space constraints or color figure charges

- Immediate publication on acceptance

- Inclusion in PubMed, CAS, Scopus and Google Scholar

- Research which is freely available for redistribution 